\title{
DOBÓR GRUNTU NA WARSTWY PRZEJŚCIOWE W ZAPORACH ZIEMNYCH NA PRZYKŁADZIE ZAPORY ŚWINNA PORĘBA
}

\author{
Zdzisław Skutnik ${ }^{\bowtie}$, Michał Cmiel \\ Instytut Inżynierii Lądowej, Szkoła Główna Gospodarstwa Wiejskiego w Warszawie
}

\begin{abstract}
STRESZCZENIE
W artykule przedstawiono rozważania na temat zasad doboru gruntu na warstwy przejściowe w zaporach ziemnych, które pełnią również funkcję filtrów odwrotnych. Skupiono się na rozpoznaniu zjawisk związanych z filtracją, w szczególności erozją wewnętrzną budowli ziemnych oraz skutecznymi metodami jej przeciwdziałania. Dokonano analizy najczęściej stosowanych zasad i kryteriów doboru gruntów na warstwy przejściowe. Zweryfikowano dobór gruntów na warstwy przejściowe zapory Świnna Poręba.
\end{abstract}

Słowa kluczowe: warstwy przejściowe, kryterium doboru, zapora ziemna, filtracja, sufozja

\section{WSTĘP}

Do najczęściej stosowanych rozwiązań przekroju poprzecznego zapór ziemnych należą zapory strefowane (Charles, 1997). Tego typu konstrukcja korpusu pozwala na minimalizację strat filtracyjnych (Jansen, Kramer, Lowe i Poulos, 1988), a także jest korzystna pod względem stateczności ogólnej i wewnętrznej, co decyduje o bezpieczeństwie budowli. Zapory strefowane są wykonywane $\mathrm{z}$ gruntów o odmiennych cechach fizykochemicznych. Taki układ wymaga odpowiedniego doboru i rozmieszczenia gruntu w korpusie zapory z uwzględnieniem zjawisk zachodzących pomiędzy elementami uszczelniającymi a nasypem statycznym (Fürstenberg, 1972). W przypadku gdy korpus zapory jest wykonany $\mathrm{z}$ gruntów przepuszczalnych, uszczelnieniem jest najczęściej ekran wykonany na skarpie odwodnej, który pełni również funkcję umocnienia skarpy. Ekrany są najczęściej wykonywane z płyt betonowych, powłok bitumicznych oraz coraz powszechniej stosowane są powłoki geosyntetyczne. W przypadku wykonania ekranu z gruntów spoistych (bardzo rzadkie rozwiązanie w polskiej strefie klimatycznej) wy- magane jest stworzenie dodatkowej warstwy ochronnej od strony skarpy oraz drenażu od strony nasypu.

Najczęściej jednak grunt spoisty wbudowany w korpus to element uszczelniający w postaci rdzenia. W przypadku zapór wysokich jest to najpowszechniejsza forma uszczelnienia. Stosowane są rdzenie pionowe bądź pochylone. Ten rodzaj konstrukcji korpusu wymaga użycia zaawansowanej procedury projektowania i budowy. Jest to rozwiązanie droższe, ale wielokrotnie sprawdzone w zaporach ziemnych na całym świecie i uznane za bezpieczne (Czyżewski, Wolski, Wójcicki i Żbikowski, 1973; Charles, 1997; Skutnik, Bajda i Lech, 2019).

\section{WARUNKI PRACY ZAPÓR ZIEMNYCH}

W procesach projektowania, budowy i eksploatacji zapór ziemnych analiza zjawiska filtracji nabiera szczególnego znaczenia (rys. 1).

Po rozpoczęciu piętrzenia przesiąkająca przez korpus i podłoże zapory woda zmienia stan gruntu, jego właściwości chemiczne i mechaniczne oraz powoduje jego odkształcenia (Barański, Król i Skutnik, 1995; 


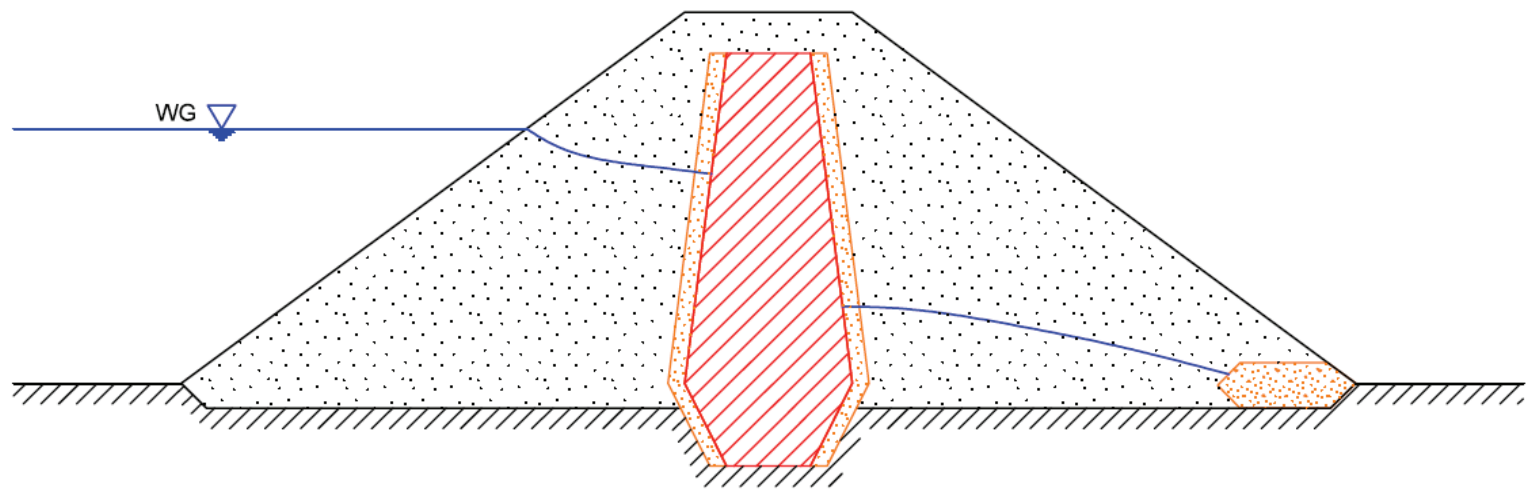

Rys. 1. Schemat filtracji przez zaporę $\mathrm{z}$ rdzeniem

Fig. 1. Filtration scheme through a dam with a core

Skutnik, 2002). Takie oddziaływania mają bezpośredni wpływ na eksploatację i bezpieczeństwo obiektu, a w szczególności na jego stateczność i trwałość. Gospodarowanie wodą $\mathrm{w}$ obiekcie $\mathrm{z}$ budowlą piętrzącą, jaką jest zapora zbiornika wodnego, powoduje częste zmiany poziomu piętrzenia wywołane realizacją bieżących zadań (ochrona przed powodzią, retencjonowanie wody, produkcja energii). Wahania poziomu piętrzenia zmieniają cechy filtracji przez korpus i podłoże zapory ziemnej. Filtrująca przez zaporę i podłoże woda jest czynnikiem wywołującym zmiany w wewnętrznej strukturze gruntu. Ruch wody oddziałuje na szkielet, doprowadzając do zmian właściwości mechanicznych, fizycznych i chemicznych gruntu. $\mathrm{Na}$ etapie projektowania, budowy i eksploatacji analiza procesu filtracji oraz zjawisk jej towarzyszących jest jednym z najważniejszych aspektów, ponieważ deformacje filtracyjne są jedną z najczęstszych przyczyn awarii ziemnych budowli piętrzących.

Jednym z negatywnych skutków nadmiernej filtracji jest sufozja. Ruch wody powoduje w niektórych przypadkach unoszenie drobnych cząstek gruntu oraz ich przemieszczenie w obrębie szkieletu gruntowego lub usunięcie poza jego obszar. Konsekwencją wymywania najdrobniejszych frakcji gruntu jest powiększanie się porów, co prowadzi do zwiększenia współczynnika filtracji. Wskutek tego zwiększa się prędkość filtracji, co przyczynia się do wymywania większych frakcji gruntu i postępu sufozji. Gruntami szczególnie narażonymi na sufozję są niespoiste grunty różnoziarniste, a więc grunty będące podstawowym materiałem budowlanym stosowanym do budowy zapór ziemnych.
Jeżeli sufozja występuje wewnątrz danego rodzaju gruntu, wówczas jest to sufozja wewnętrzna, zaś gdy występuje na styku różnych warstw gruntu lub w strefie przypowierzchniowej budowli ziemnej jest to sufozja zewnętrzna i kontaktowa (Dąbska i Popielski, 2019). Postępująca sufozja i zwiększanie się porów gruntowych w konsekwencji prowadzi do powstania przebicia hydraulicznego, czyli powstania w strukturze gruntu kanalików łączących ośrodki o wyższym i niższym ciśnieniu, które wypełnione są gruntem o naruszonej strukturze, a w końcowej fazie zawiesiną. Płynąca woda doprowadza do odrywania się coraz większych frakcji i tworzenia się coraz większych kanałów. Przebicie hydrauliczne można zaobserwować w sąsiedztwie ziemnych budowli piętrzących wodę stale lub okresowo, a w szczególności w pobliżu wałów przeciwpowodziowych w czasie przejścia fali wezbraniowej. Niejednokrotnie przebicie hydrauliczne doprowadziło do przerwania wału, a w efekcie zalania całej doliny. W przypadku występowania intensywnej filtracji może dojść do znacznego wzrostu ciśnienia wody w porach (naprężenia efektywne $\sigma^{\prime}=0$ ), a w następstwie upłynnienia gruntu (kurzawki) - wówczas szkielet gruntowy przechodzi w stan płynny, cząstki gruntu są unoszone w wodzie, zanika wzajemny kontakt. Grupa gruntów szczególnie narażonych na upłynnienie są piaski drobne, lecz w szczególnych przypadkach (duże gradienty) może ono również występować w gruntach gruboziarnistych. Sufozja wewnętrzna w konstrukcji obiektów piętrzących wodę jest zjawiskiem często niezauważalnym aż do momentu zniszczenia. Dotyczy to szczególnie obiektów, na których nie zamon- 
towano aparatury kontrolno-pomiarowej. Tego typu przypadki to głównie małe obiekty piętrzące. Zmiany filtracyjne w korpusie można wykryć na podstawie obserwacji wody w studniach rewizyjnych drenaży przyskarpowych. W przypadku zwiększenia wydatku oraz mętności wody wypływającej z drenaży można wnioskować, że w korpusie postępuje sufozja.
Gdy postępujące odkształcenia filtracyjne nie zostaną wykryte, w odpowiednim czasie może dojść do całkowitego zniszczenia konstrukcji. Taki przypadek przedstawiono na rysunku 2 . W ciągu jednej doby doszło do całkowitego zniszczenia zapory w wyniku postępującej sufozji wewnętrznej, której następstwem było przerwanie zapory. Od rozpoczęcia niepozornego

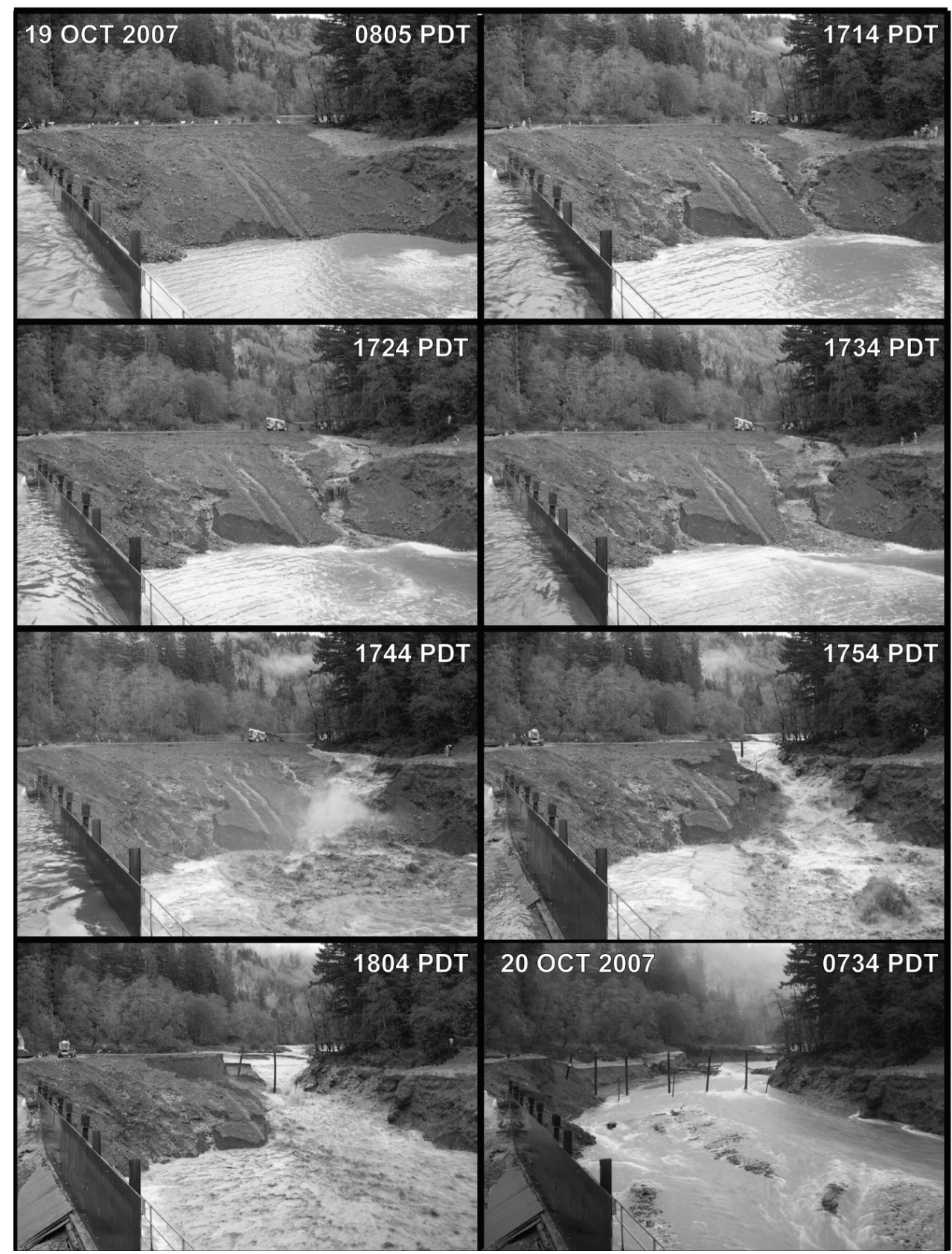

Rys. 2. Przykład postępującej erozji na zaporze Marmot (Major, Keith, O’Connor i Wallick, 2016)

Fig. 2. Example of progressive erosion of the Marmot Dam (Major, Keith, O'Connor \& Wallick, 2016) 
sączenia wody ze skarpy odpowietrznej do całkowitego zniszczenia obiektu minęło zaledwie dziesięć godzin. Ten przykład pokazuje, jak szybko mogą zachodzić procesy towarzyszące niekontrolowanej filtracji oraz jakie są tego konsekwencje.

\section{METODYKA DOBORU GRUNTÓW NA WARSTWY PRZEJŚCIOWE ZAPORY}

Właściwy dobór warstw przejściowych i drenażowych jest jednym z najważniejszych aspektów decydujących o bezpiecznej eksploatacji zapory (ICOLD, 1994; Barański, Król i Wolski, 1995). W przeszłości odnotowano wiele przypadków awarii lub zagrożeń awarią wywołanych brakiem lub nieodpowiednim wykonaniem tych warstw. Warstwy przejściowe, zwane też filtrami odwrotnymi, to konstrukcje gruntowe o odpowiednio dobranym uziarnieniu, stosowane na styku warstw gruntów o znacząco różniących się właściwościach, wokół rur drenażowych czy też w miejscu ewentualnego wypływu wody na skarpę. Rolą warstwy przejściowej jest zabezpieczanie przed przenikaniem drobnych cząstek gruntu chronionego do filtra, zapewnienie miejscowego zakolmatowania filtru w sytuacjach skrajnych (np. gdy miejscowe odkształcenie rdzenia prowadzi do powstania szczelin w masywie uszczelnienia), łagodzenie zakłóceń w rozkładzie stanu naprężenia pomiędzy ściśliwym rdzeniem a nasypem statycznym, odprowadzenie wód pochodzących z przecieków z materiału stanowiącego uszczelnienie zapory bez nadmiernego wzrostu ciśnienia hydrostatycznego, zabezpieczanie przed sufozją (niebezpieczną dla stateczności gruntu chronionego). W zależności od warunków warstwy przejściowe mogą składać się z jednej lub kilku warstw o odpowiednio dobranym uziarnieniu. Ich działanie polega na zmniejszaniu spadku hydraulicznego w wyniku zwiększania współczynnika filtracji kolejnych warstw. Uziarnienie poszczególnych warstw zwiększa się z kierunkiem filtrującej wody.

Projektowanie warstw przejściowych w zaporach ziemnych polega na dobraniu uziarnienia gruntu chroniącego do uziarnienia gruntu chronionego, spełniając równocześniekryteriumprzepuszczalności, uziarnienia i stabilności (Messerklinger, 2013; Yang, Yin, Laouafa i Hicher, 2020). Rozwój budownictwa hydrotechnicz- nego w ubiegłym wieku sprawił, że tematyce warstw przejściowych towarzyszyło znaczne zainteresowanie, wykonano wiele badań laboratoryjnych i modelowych. $\mathrm{W}$ tym czasie powstało wiele kryteriów oraz metod doboru gruntu na warstwy przejściowe. Kryteria opracowane w latach 40. i 60. uwzględniały wytrzymałość gruntu chronionego (rdzenia) na rozciąganie. W latach 80. opracowano metodę, według której filtr miał całkowicie zabezpieczać rdzeń przed ubytkiem materiału rdzenia, tzw. filtr zupełny (Vaughan i Soares, 1982). To podejście spotkało się z krytyką, gdyż było zbyt zachowawcze i prowadziło do przewymiarowania filtrów. Wykazano to w licznych badaniach i opracowaniach, a efektem tych prac była propozycja kryterium filtru tzw. krytycznego (Sherard, Dunningan i Talbot, 1984; Sherard, 1986) - przykładowo dla gruntu pylastego o średnicy $d_{85}=0,03-0,10 \mathrm{~mm}$ zaleca się filtr o średnicy $D_{15}<0,03 \mathrm{~mm}$.

Prowadzone na przestrzeni wieków badania oraz doświadczenia pokazały, że jednym z najbardziej trafnych i słusznych jest kryterium podane w 1922 roku przez Terzaghiego (Wolski, 1967).

$$
\begin{aligned}
& \frac{D_{15}}{d_{15}} \geq 4 \\
& \frac{D_{15}}{d_{85}} \leq 4
\end{aligned}
$$

Po przekształceniu:

$$
4 d_{15} \leq D_{15} \leq 4 d_{85}
$$

W przypadku gdy warstwa filtru styka się z rurą drenażową, dodatkowe kryterium wygląda następująco:

$$
D_{80} \geq S
$$

gdzie:

$D_{15}, D_{80}$ - średnica zastępcza ziaren gruntu filtru, którego zawartość wraz z mniejszymi wynosi $15 \%[\mathrm{~mm}]$,

$d_{15}, d_{85}$ - średnica zastępcza ziaren gruntu chronionego, których zawartość wraz z mniejszymi wynosi odpowiednio $15 \%$ i $85 \%$ [mm].

$S \quad-$ szerokość szczeliny wlotowej drenu [mm]. 
Procedura wyznaczania uziarnienia gruntu na warstwy ochronne według Terzaghiego polega na wyznaczeniu średnic ziaren gruntu ochranianego, których zawartość wraz z mniejszymi ziarnami stanowi odpowiednio $15 \%$ i $85 \%-d_{15}$ i $d_{85}$. Następnie wyznaczamy zakres uziarnienia warstwy przejściowej na podstawie zależności podanych przez Terzaghiego (wzór 3) oraz uprzednio określonych średnic ziaren $d_{15}$ i $d_{85}$. Na podstawie wyznaczonego zakresu średnicy $D_{15}$ gruntu chronionego, zachowując zasadę równoległości krzywych, wyznacza się zakres uziarnienia gruntów, które moga pełnić funkcję ochraniającą grunt. $Z$ uzyskanego zakresu, w miarę możliwości, równolegle do krzywej uziarnienia gruntu wyznacza się krzywą uziarnienia gruntu przeznaczonego na warstwę przejściową (warunek niekonieczny).

Skład granulometryczny gruntu przeznaczonego na warstwę przejściową (ICOLD, 1994) musi być dobrany tak, aby: materiał przeznaczony na filtr podczas transportu, rozkładania i zagęszczania nie podlegał segregacji; był na tyle jednorodny, żeby współczynnik filtracji w całej warstwie był jednakowy; nie podlegał degradacji w wyniku przetwarzania (transportu, zagęszczania) czy też pod wpływem niekorzystnych warunków atmosferycznych (zamarzanie, rozmarzanie); wbudowany w warstwę składał się z trwałych cząstek odpornych na procesy fizykochemiczne. Warstwa przejściowa musi zaś pozostać niespójna, nawet gdy w rdzeniu powstaną pęknięcia lub szczeliny, co zapewni ich uszczelnienie (Lo i Kaniaru, 1990).

Dobierając grunt na warstwy przejściowe, jednym z najważniejszych aspektów jest sprawdzenie podatności na wewnętrzną sufozję gruntu chroniącego przeznaczonego na filtr. W trakcie projektowania zapory ziemnej stosuje się obszerne badania laboratoryjne pozwalające sprawdzić, jak zachowa się dany grunt pod wpływem sił filtracji o zadanym gradiencie hydraulicznym. Poza badaniami laboratoryjnymi istnieje wiele skutecznych metod analitycznych pozwalających na sprawdzenie wewnętrznej stabilności gruntu. Do jednych ze skuteczniejszych i z latwych w zastosowaniu metod kontroli wewnętrznej stabilności gruntu należy graficzna metoda oceny sufozyjności podana przez Kenneya i Lau w 1985 roku (rys. 3 i 4). Według nich czynnikiem mającym znaczacy wpływ na wewnętrzną stabilność gruntu jest kształt krzywej uziarnienia (Rönnqvist i Viklander, 2014). Odpowiednie opisanie krzywej pozwala na sklasyfikowanie gruntu jako wewnętrznie stabilny lub niestabilny. Opis kształtu krzywej uziarnienia polega na określeniu dla dowolnie dużej liczby punktów wartości $F$ i $H$, przy czym $F$

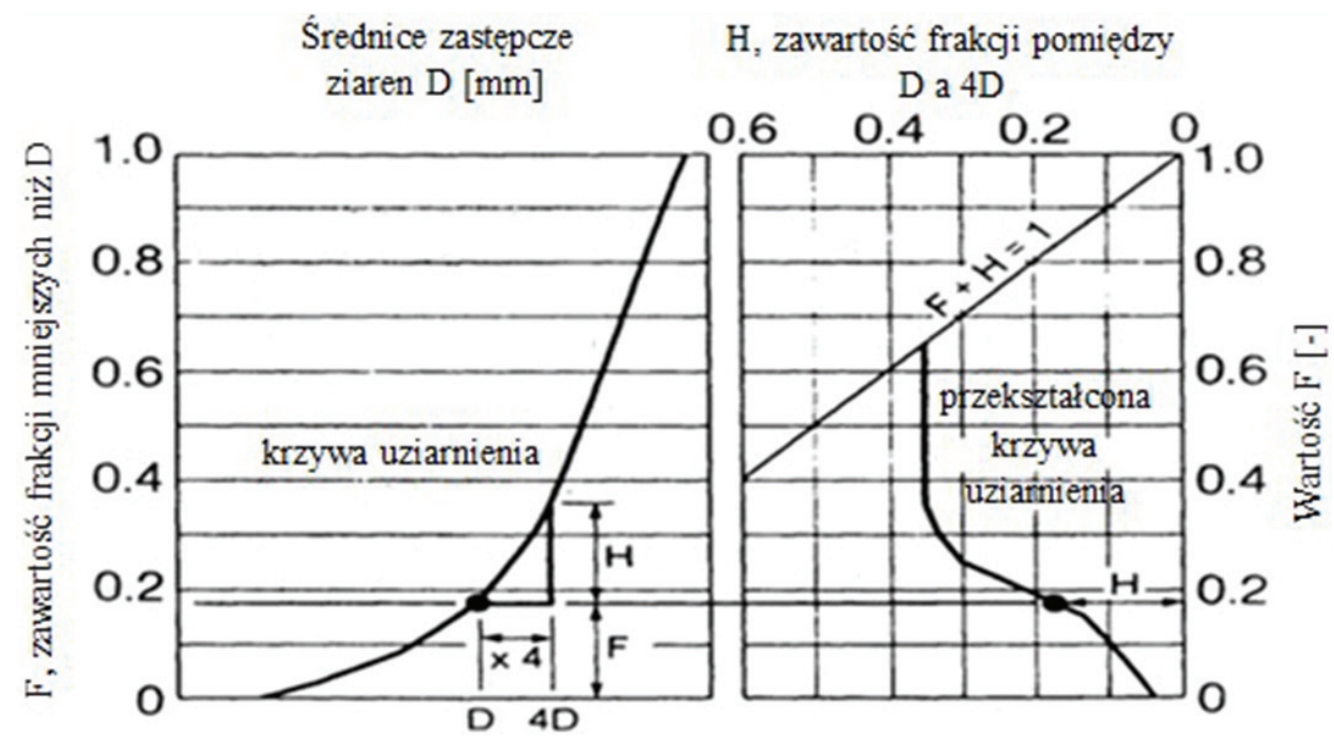

Rys. 3. Przekształcenie krzywej uziarnienia według metody Kenneya (ICOLD, 2015)

Fig. 3. Transformation of the grain size curve according to the Kenney method (ICOLD, 2015) 
oznacza procentową zawartość frakcji mniejszych od średnicy $D$, a $H$ procentową zawartość frakcji między $D$ i $4 D$. Średnica $4 D$ wynika z metody projektowania filtru według kryteriów Terzaghiego.

Na rysunku 3 przedstawiono metodykę przekształcenia klasycznej krzywej uziarnienia w celu określenia wewnętrznej stabilności gruntu. Dla dowolnie wybranych średnic zastępczych $d$ należy wyznaczyć ich czterokrotność, a następnie odczytać zawartość frakcji zawartych w przedziale pomiędzy $d$ a $4 d(H)$ oraz frakcji mniejszych od średnicy $d(F)$. Im więcej punktów zostanie wybranych, tym charakterystyka krzywej będzie dokładniejsza. Mając wartości $F$ i $H$, należy stworzyć przekształconą krzywą uziarnienia. Na osi poziomej nanieść wartości $F$, a na osi pionowej $H$. Wartość $F+H=100 \%$, dlatego na wykresie należy zamieścić odciętą o nachyleniu $45^{\circ}$. Klasyfikacji gruntu ze względu na jego sufozyjność dokonuje się w zależności od położenia względem pasa rozgraniczającego. Pierwotnie, według Kenneya i Lau, współrzędne linii środkowej pasa wynosiły $F-H$ : $0-0$ i $0,3-0,4$. W wyniku licznych analiz stwierdzono, że pas o takich współrzędnych jest zbyt „rygorystyczny". Maranha das Neves (1989) zaproponował, aby współrzędne pasa rozgraniczającego wynosiły $F-H$ : $0-0$ i $0,4-0,4$. W ten sposób uzyskano ,łagodniej- sze" kryterium, dla którego linia środkowa pasa jest nachylona do poziomu pod kątem $45^{\circ}$. Na rysunku 4 przedstawiono przykłady przekształconych krzywych uziarnienia poddanych analizie stabilności.

Na rysunku 4, na wykresie po lewej zamieszczono grunty o uziarnieniu niestabilnym. Krzywe znajduja się poniżej pasa rozgraniczającego. Na rysunku 4, na wykresie po prawej zamieszczono krzywe dla gruntów o stabilnym uziarnieniu. Rozpatrywane grunty znajdują się powyżej pasa rozgraniczającego, dlatego można stwierdzić, że ich uziarnienie jest stabilne. Analiza stabilności wewnętrznej gruntu pozwala w praktyce na uniknięcie niekorzystnych zjawisk fizykochemicznych w obrębie warstwy przejściowej oraz na styku z gruntami chronionymi, mogących w konsekwencji prowadzić do awarii zapory, a w skrajnych przypadkach do zniszczenia całego obiektu.

\section{WERYFIKACJA DOBORU WARSTW PRZEJŚCIOWYCH W ZAPORZE ŚWINNA PORĘBA}

W zaporze Świnna Poręba występują dwie warstwy przejściowe chroniące rdzeń o nachyleniu $9: 1$. Szerokość pierwszej warstwy przejściowej wynosi $1 \mathrm{~m}$, a szerokość drugiej warstwy $2 \mathrm{~m}$. U podnóża skarpy odwodnej znajduje się drenaż płaski. Odbiornikiem
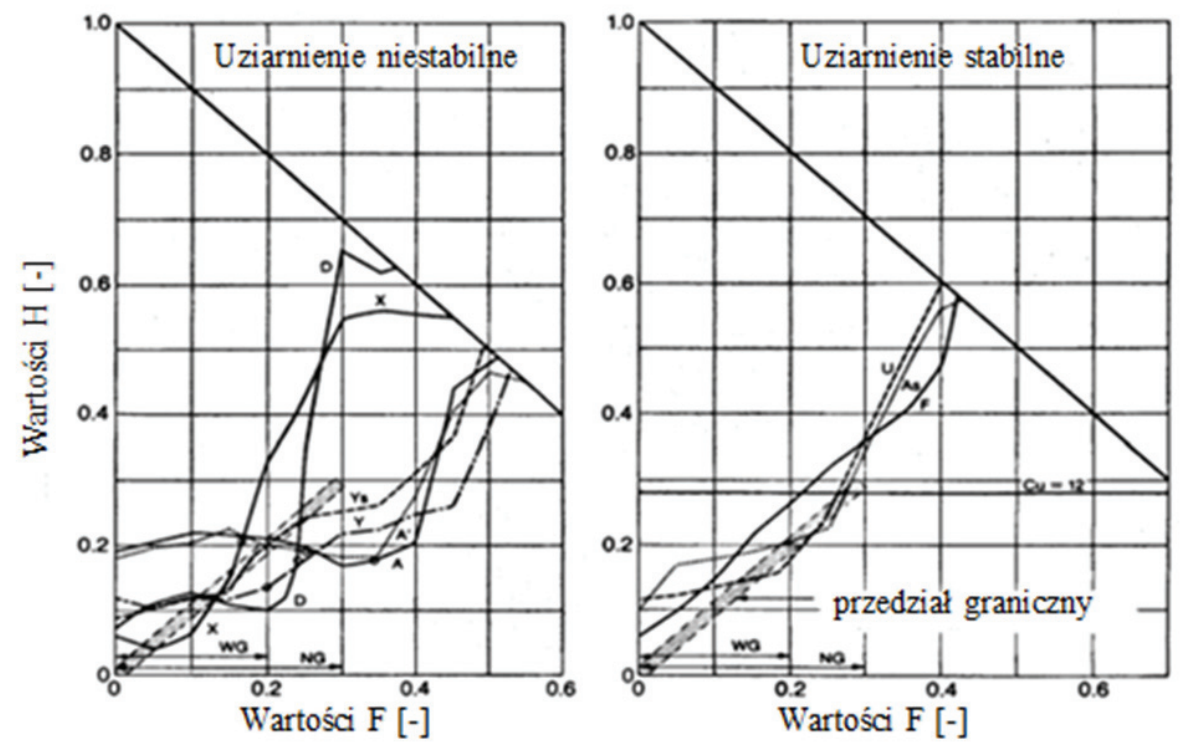

Rys. 4. Przykłady stabilnych i niestabilnych przekształconych krzywych uziarnienia gruntu (ICOLD, 2015)

Fig. 4. Examples of stable and unstable transformed soil grain size curves (ICOLD, 2015) 


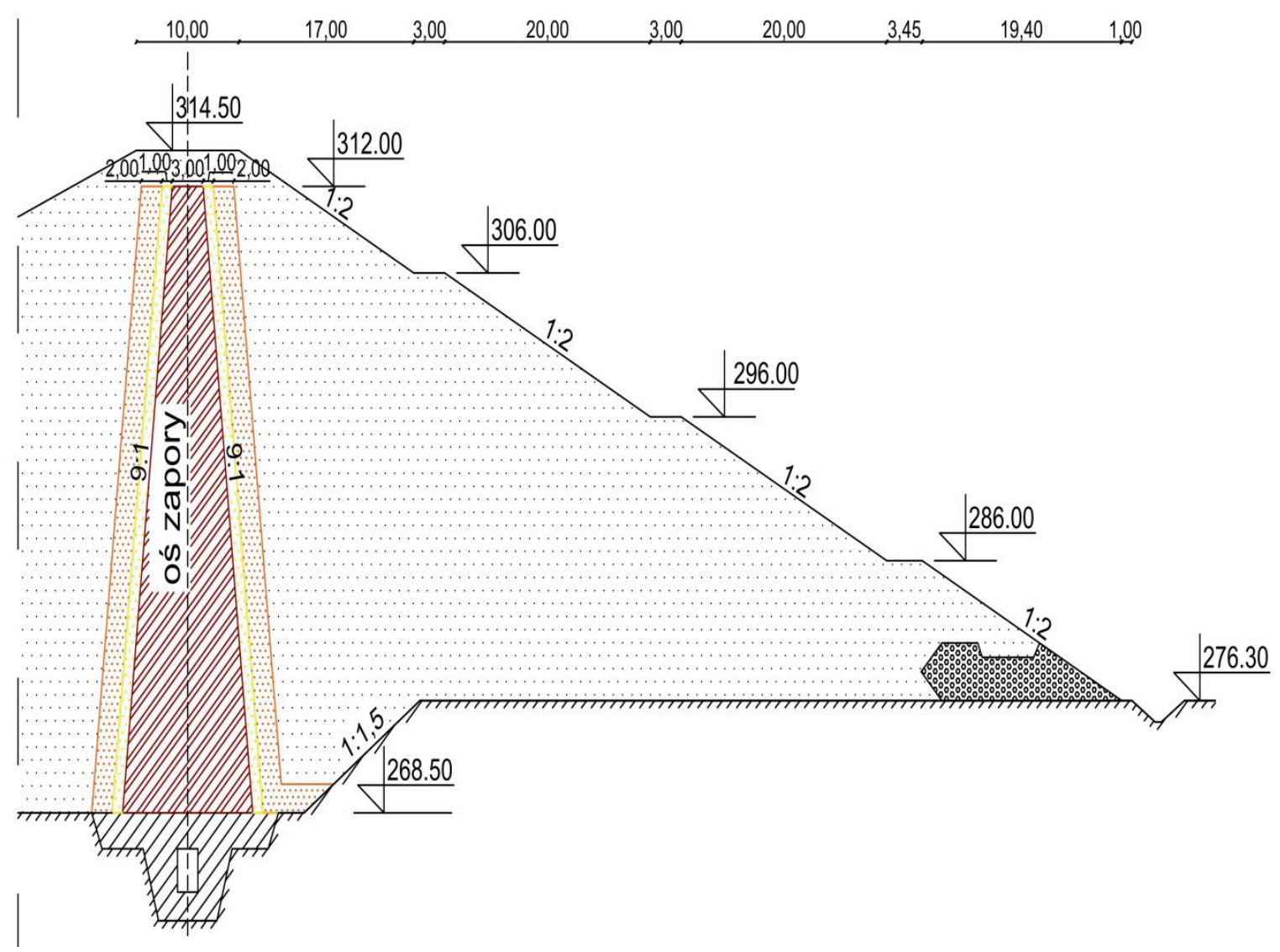

Rys. 5. Przekrój poprzeczny przez rdzeń, warstwy ochronne i warstwę drenażową zapory Świnna Poręba

Fig. 5. Cross section through the core, filters and drainage layer of the Świnna Poręba Dam

wód drenażowych jest rów biegnący wzdłuż zapory. Szczegóły rozwiązania przedstawiono na zgeneralizowanym przekroju (rys. 5).

Złoże, z którego zbudowano rdzeń w zaporze Świnna Poręba, cechowało się dużą zmiennością. Przeważały gliny pylaste, pylaste zwięzłe z lokalnymi pokładami pospółek. Podczas budowy rdzenia materiał był mieszany w celu uzyskania jak najbardziej jednolitej masy. Uśrednioną krzywą uziarnienia gruntu wbudowanego w rdzeń, którą przyjęto do doboru i weryfikacji uziarnienia warstw przejściowych, przedstawiono na rysunku 6.

Według kryterium Terzaghiego (wzór 3) wyznaczono dopuszczalny zakres uziarnienia pierwszej warstwy przejściowej:

$$
\begin{aligned}
4 \cdot 0,002 \mathrm{~mm} & \leq D_{15} \leq 4 \cdot 0,18 \mathrm{~mm} \\
0,008 \mathrm{~mm} & \leq D_{15} \leq 0,72 \mathrm{~mm}
\end{aligned}
$$

Następnie obliczono, że średnica $D_{15}$ pierwszej warstwy przejściowej powinna zawierać się przedziale od 0,008 do $0,72 \mathrm{~mm}$. Tak szeroki zakres dopuszczalnego uziarnienia wynika z dużej różnoziarnistości materiału, z którego zbudowany jest rdzeń. Na rysunku 7 przedstawiono wyznaczony dopuszczalny zakres uziarnienia (obszar zakreskowany) oraz dobraną na pierwszą warstwę przejściową krzywą uziarnienia gruntu.

W celu weryfikacji poprawności doboru gruntu sprawdzono jego wewnętrzną stabilność, wykorzystując do tego metodę graficzną Kenneya i Lau. Krzywą uziarnienia gruntu pierwszej warstwy przejściowej scharakteryzowano za pomocą 10 punktów, dla których wyznaczono wartości $F$ i $H$, na podstawie których stworzono przekształconą krzywą uziarnienia (rys. 8). 


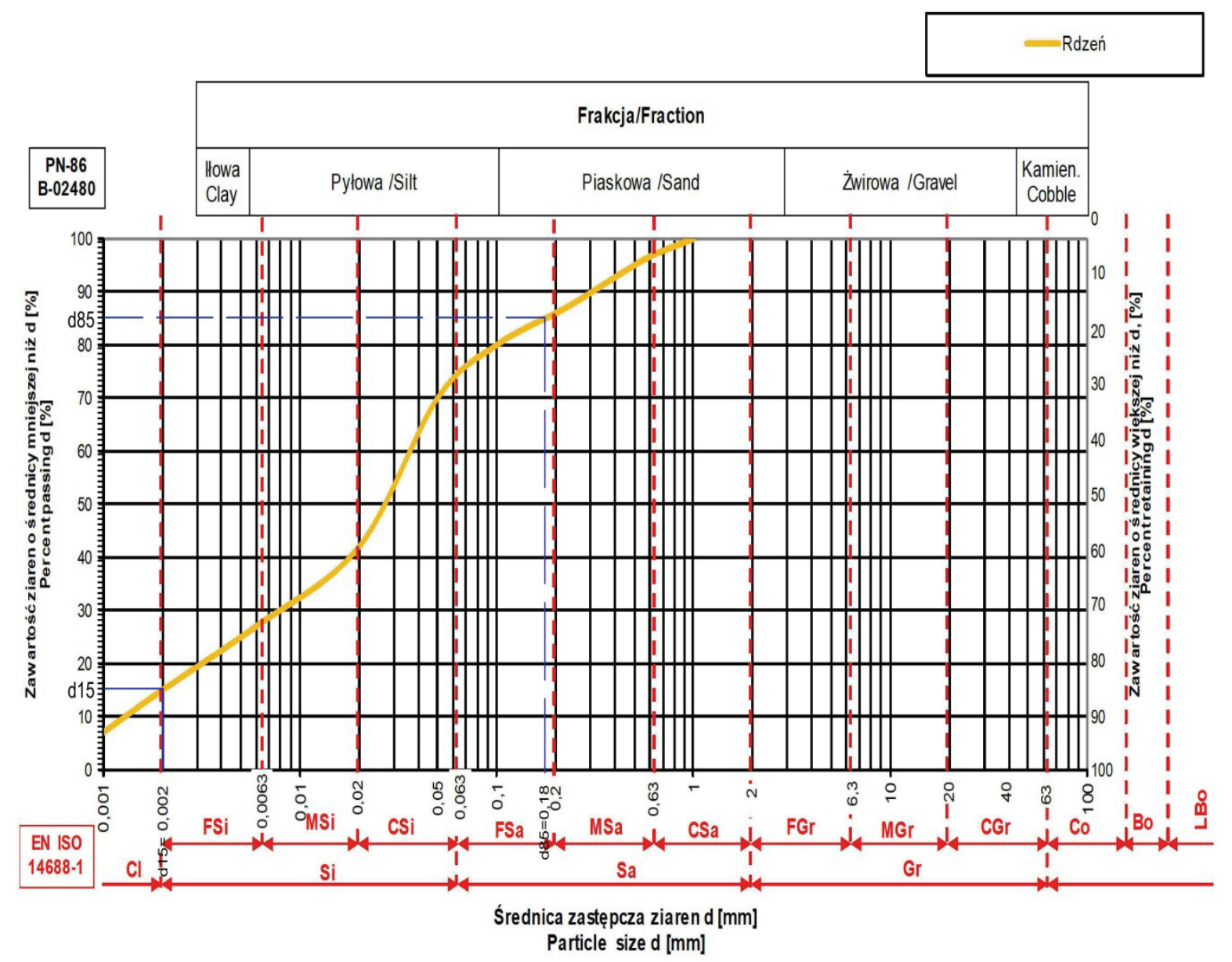

Rys. 6. Krzywa uziarnienia rdzenia przyjęta w procedurze doboru gruntu na warstwy przejściowe

Fig. 6. Grain size curve of dam core adopted in the procedure of soil selection for transition layers

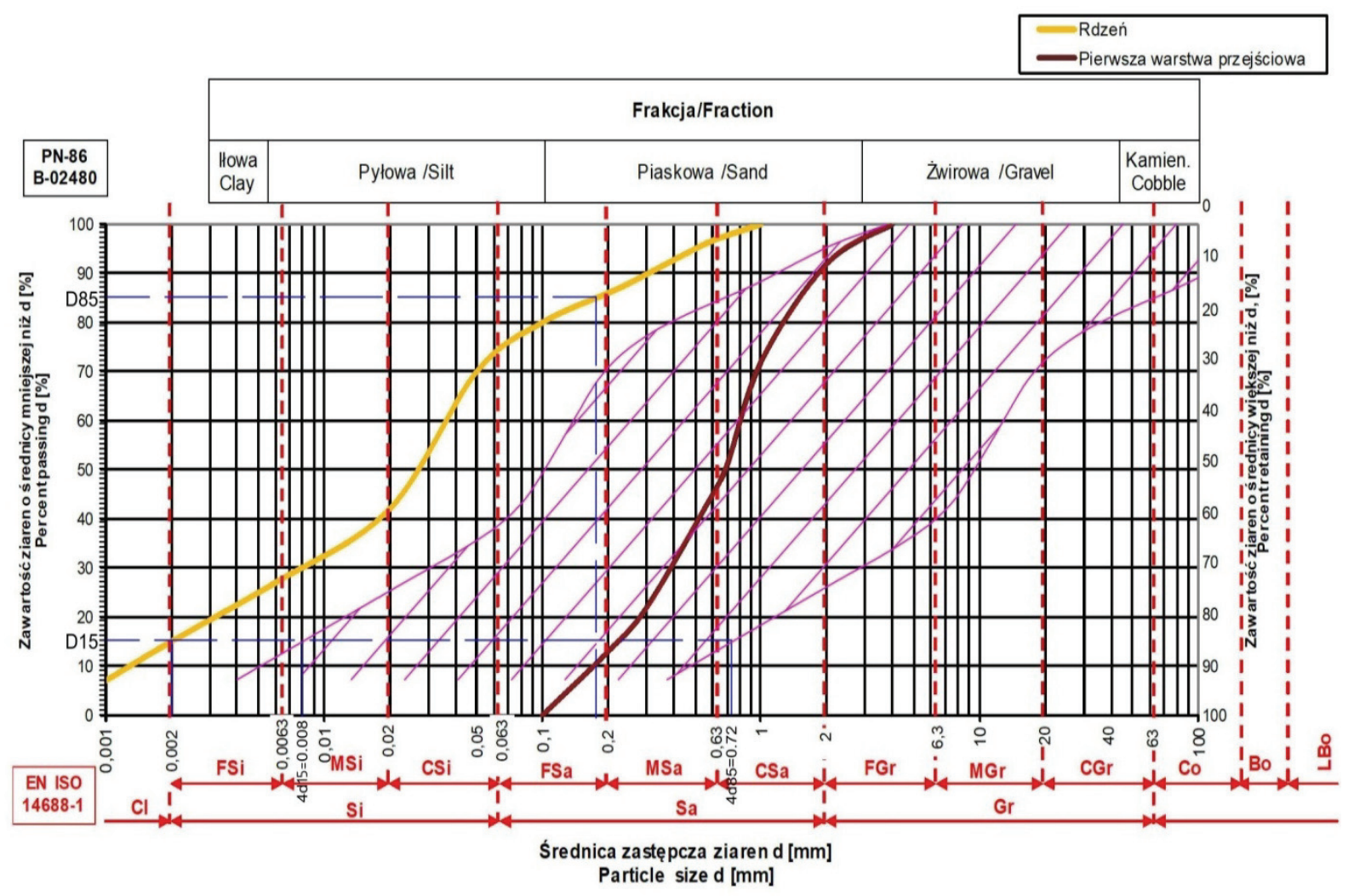

Rys. 7. Dobór gruntu na pierwszą warstwę przejściową

Fig. 7. Soil selection for the first transition layer 
Rys. 8. Przekształcona krzywa uziarnienia gruntu na pierwszą warstwę przejściową w zaporze Świnna Poręba

Fig. 8. Transformed soil grain size curve for the first transitional layer in the Świnna Poręba Dam

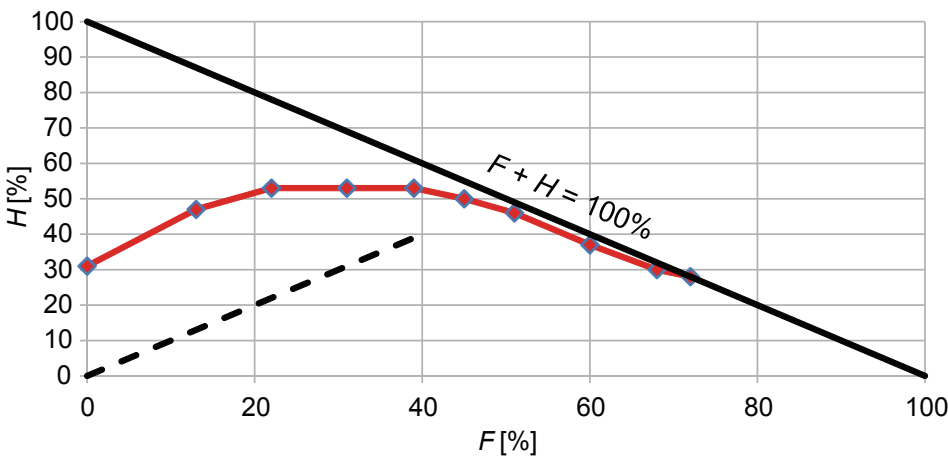

i $d_{85}$ warstwy pierwszej oraz na podstawie wzoru (3) wyznaczono dopuszczalny zakres uziarnienia drugiej warstwy przejściowej:

$$
\begin{gathered}
4 \cdot 0,22 \mathrm{~mm} \leq D_{15} \leq 4 \cdot 0,88 \mathrm{~mm} \\
0,88 \mathrm{~mm} \leq D_{15} \leq 6,4 \mathrm{~mm}
\end{gathered}
$$

Obliczono, że średnica $D_{15}$ drugiej warstwy przejściowej powinna zawierać się w przedziale od 0,88 do $6,4 \mathrm{~mm}$. Na rysunku 9 przedstawiono wyznaczony padku gruntem chronionym będzie pierwsza warstwa przejściowa. W tym celu wyznaczono średnice $d_{15}$

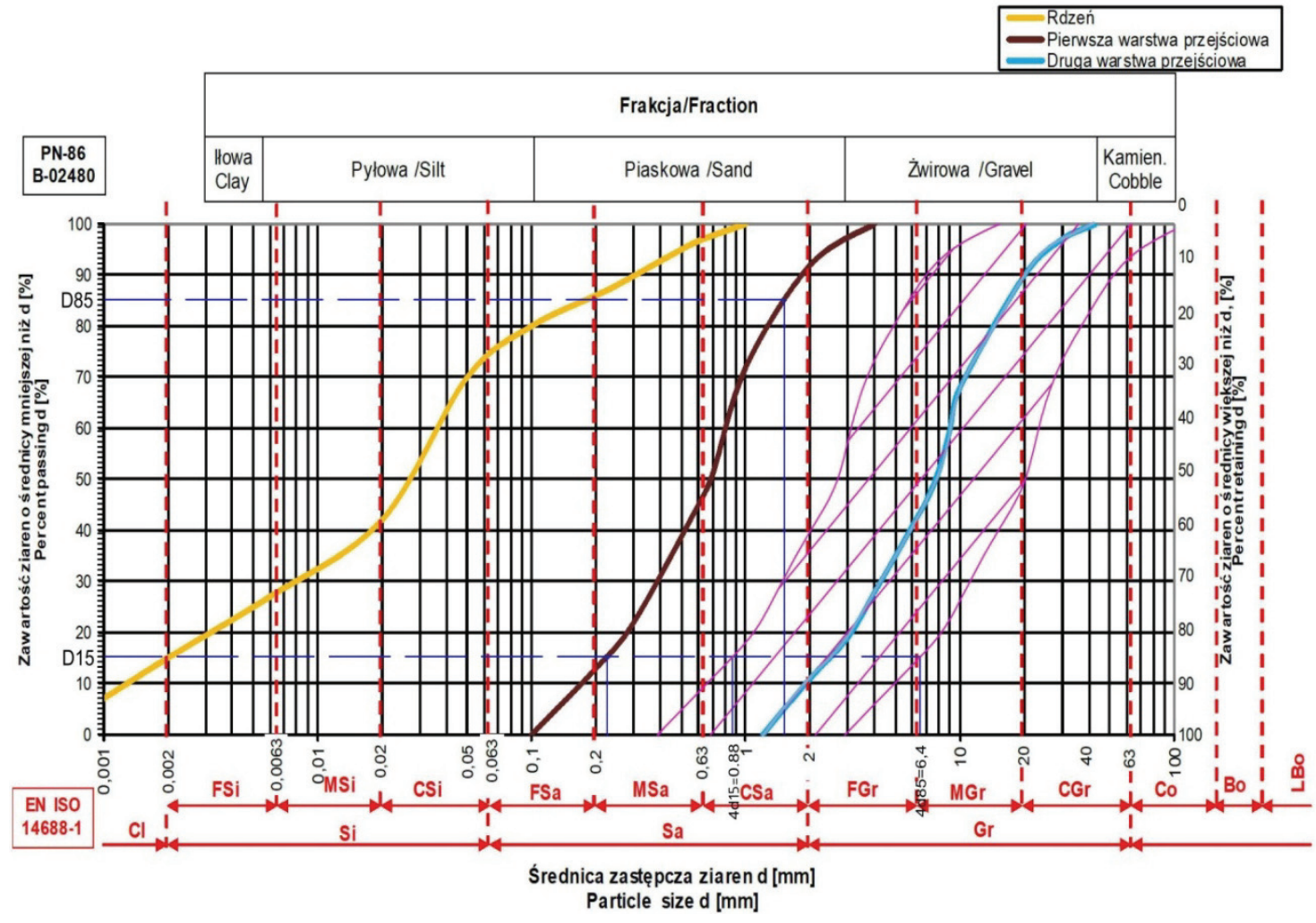

Rys. 9. Dobór gruntu na drugą warstwę przejściową

Fig. 9. Soil selection for the second transition layer 
Rys. 10. Przekształcona krzywa uziarnienia gruntu na drugą warstwę przejściową w zaporze Świnna Poręba

Fig. 10. Transformed soil grain size curve for the second transitional layer in the Świnna Poręba Dam

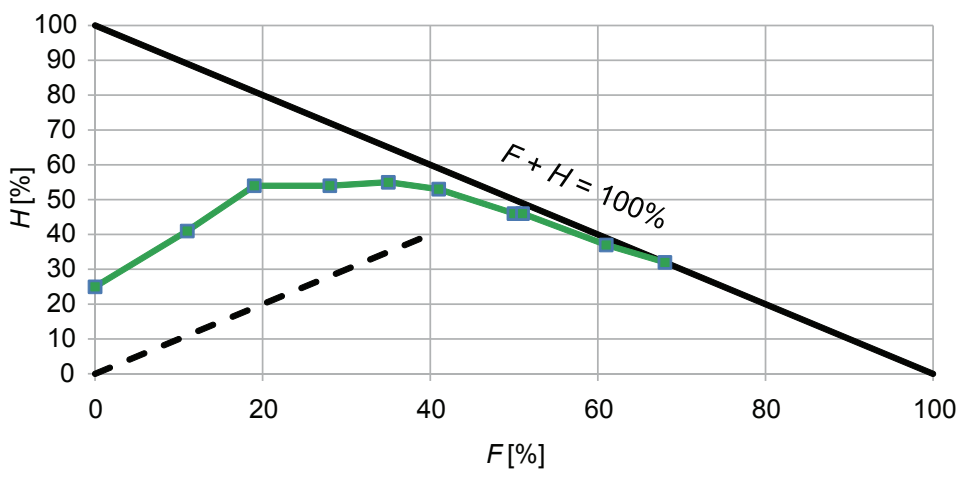

dopuszczalny zakres uziarnienia (obszar zakreskowany) oraz dobraną krzywą uziarnienia gruntu na drugą warstwę przejściową.

Następnie przystąpiono do sprawdzenia wewnętrznej stabilności gruntu. Krzywą uziarnienia gruntu drugiej warstwy przejściowej scharakteryzowano za pomocą 10 punktów, dla których wyznaczono wartości $F$ i $H$, a na ich podstawie stworzono przekształconą krzywą uziarnienia (rys. 10).

Podobnie jak w przypadku pierwszej warstwy można stwierdzić, że grunt na drugą warstwę przejściową został dobrany prawidłowo. Krzywa znajduje się powyżej pasa rozgraniczającego, zatem grunt jest stabilny wewnętrznie.

\section{WNIOSKI}

Budowane w ostatnich latach zapory to najczęściej obiekty o konstrukcji strefowanej $\mathrm{z}$ uszczelnieniem wykonanym $\mathrm{z}$ gruntów spoistych w postaci rdzenia. Obserwacje prowadzone na eksploatowanych zaporach ziemnych w Polsce i na świecie wykazały, że do najczęściej występujących, niekorzystnych zjawisk towarzyszących filtracji przez korpus i podłoże zapory ziemnej należą sufozja i upłynnienie gruntu, rzadziej dyspersja. Odkształcenia filtracyjne mają często bardzo ekspansywny charakter. Potwierdzają to przypadki awarii i katastrof zapór ziemnych wywołanych niekontrolowaną filtracją.

Do najczęściej stosowanych zabezpieczeń gruntu przed erozją wewnętrzną można zaliczyć warstwy przejściowe (filtry odwrotne) oraz zabezpieczenia wydłużające drogę filtracji. Za jedno z najbardziej trafnych, choć opartych w większości na inżynierskiej intuicji, uznaje się kryterium podane przez Terzaghiena cechach granulometrycznych gruntu, a w szczególności średnic $d_{15}$ i $d_{85}$ gruntu chronionego. Można to uznać za dość bezkrytyczne podejście z uwagi na to, że średnice $d_{15}$ i $d_{85}$ nie w pełni charakteryzują dany grunt.

Podczas doboru gruntu na warstwy przejściowe w zaporze Świnna Poręba zauważono, że grunt chroniony (rdzeń zapory) cechuje duży wskaźnik różnoziarnistości. W takiej sytuacji istnieje duża swoboda wyboru gruntu na warstwę przejściową. Grunty niespoiste, cechujące się dużym wskaźnikiem różnoziarnistości, poddane ocenie za pomocą metody Kenneya i Lau określono jako wewnętrznie niestabilne. Stąd Kenney uściślił warunki dotyczące filtru, wprowadzając między innymi wymaganie, aby wskaźnik różnoziarnistości $\left(C_{u}=d_{60} / d_{10}\right)$ był mniejszy lub równy 6 .

Poza uziarnieniem gruntu należy brać pod uwagę również odporność cząstek na działania mechaniczne (załadunek, transport, zagęszczanie). Zaleca się wykonywać próbne wbudowanie gruntu $\mathrm{w}$ warstwę przejściową $\mathrm{w}$ warunkach terenowych i przeprowadzenie badań uziarnienia i współczynnika filtracji. W technologii wykonania warstw przejściowych należy do minimum ograniczyć zabiegi związane $\mathrm{z}$ transportem materiału, a w szczególności operacje związane z załadunkiem i rozładunkiem, co zazwyczaj powoduje wzrost zawartości podziarna i w konsekwencji zmniejszenie współczynnika filtracji. go. Zarówno to, jak i inne kryteria opierają się głównie 


\section{Indywidualny wkład autorów}

Opracowanie: Z.S. i M.C.; metodologia: M.C.; oprogramowanie: Z.S. i M.C.; walidacja: Z.S. i M.C.; analiza formalna: Z.S.; badanie: M.C.; kompilacja i opracowanie danych: M.C.; sporządzenie wstępnej wersji artykułu: Z.S. i M.C.; redakcja i korekta artykułu: Z.S.; wizualizacja: Z.S. i M.C.; zarządzanie projektem: Z.S. i M.C.

Wszyscy autorzy zapoznali się z przeznaczoną do publikacji wersją manuskryptu.

\section{PIŚMIENNICTWO}

Barański, T., Król, P. i Wolski, W. (1995). Problematyka warstw przejściowych w zaporach Czorsztyn i Klimkówka. W W. Wolski (red.), Zagadnienia konstrukcyjno-budowlane zapór Czorsztyn i Klimkówka (strony 156-176). Warszawa: SKHKILiW PAN.

Barański, T., Król, P., Skutnik, Z. i Wolski, W. (1995). Kompleksowe badania jakości rdzenia zapór Czorsztyn i Klimkówka. W W. Wolski (red.), Zagadnienia konstrukcyjno-budowlane zapór Czorsztyn i Klimkówka (strony 138-155). Warszawa: SKHKILiW PAN.

Charles, J. A. (1997). General report. Special problems associated with Earthfill dams. W Nineteenth International Congress on Large Dams, 26-30 May, Florence, Italy, GR Q.73. Vol. II (strony 1083-1198). Paris: International Commision on Large Dams.

Czyżewski, K., Wolski, W., Wójcicki, S. i Żbikowski, A. (1973). Zapory ziemne. Warszawa: Wydawnictwo Arkady.

Dąbska, A. i Popielski, P. (2019). Deformacje filtracyjne gruntów - klasyfikacja. Gospodarka Wodna, 8, 7-13.

Fürstenberg, A. (1972). Próba określenia odksztatceń gruntu rdzenia zapory $w$ sasiedztwie styku $z$ warstwami ochronnymi $w$ świetle badań modelowych (rozprawa doktorska). Szkoła Główna Gospodarstwa Wiejskiego w Warszawie, Warszawa.

International Commission on Large Dams [ICOLD] (1994). Embankment dams, granular filters and drains. Review and recommendations. ICOLD Bulletin 95. Paris: International Commission on Large Dams.

International Commission on Large Dams [ICOLD] (2015). Internal erosion of existing dams, levees and dikes, and their foundations. ICOLD Bulletin 164 (Vol. 1). Paris: International Commission on Large Dams.
Jansen, R. B., Kramer, R. W., Lowe, J. III, Poulos, S. J. (1988). Earthfill dam design and analysis. W R. B. Jensen (red.), Advanced Dam Engineering for Design, Construction and Rehabilitation (strony 256-320). New York: Van Nostrand Reinhold.

Kenney, T. C. i Lau, D. (1985). Internal Stability of Granular Filters. Canadian Geotechnical Journal, 22, 215-225. http://doi.org/10.1139/t85-029

Lo, K. Y. i Kaniaru, K. (1990). Hydraulic fracture in earth and rock-fill dams. Canadian Geotechnical Journal, 27 (4), 496-506.

Major, J., Keith, M., O’Connor, J. i Wallick, R. (2016). An example of one river's response to a large dam removal. Key Concepts in Geomorphology Vignettes and Case Studies. https://serc.carleton.edu/39733

Maranha das Neves, E. (1989). Analysis of Crack Erosion in Dam Cores: The Crack Erosion Test. W O. A. Varde (red.), De Mello Volume: A Tribute to Prof. Dr. Victor F.B de Mello (strony 284-298). Sao Paulo: Edgar Blucher.

Messerklinger, S. (2013). The Design of Filter Materials and their Importance in Geotechnical Engineering. W P. Delage $\mathrm{i}$ in. (red.), Proceedings of the 18th International Conference on Soil Mechanics and Geotechnical Engineering "Challenges and Innovations in Geotechnics" (strony: 3313-3316). Paris: Presses des Ponts.

Rönnqvist, H. i Viklander, P. (2014) On the Kenney-Lau Approach to Internal Stability Evaluation of Soils. Geomaterials, 4, 129-140. http://doi.org/10.4236/ gm.2014.44013

Sherard, J. L. (1986). Hydraulic fracturing in embankment dams. Journal of Geotechnical Engineering, 112 (10), 905-927.

Sherard, J. L., Dunningan, L. P. i Talbot, J. R. (1984). Filters for silts and clays. Journal of the Geotechnical Engineering, 110 (1), 701-718.

Skutnik, Z. (2002): Weryfikacja parametrów geotechnicznych rdzenia zapory nasypowej na podstawie badań prowadzonych podczas budowy (rozprawa doktorska). Szkoła Główna Gospodarstwa Wiejskiego w Warszawie, Warszawa.

Skutnik, Z., Bajda, M. i Lech, M. (2019). The selection of sealing technologies of the subsoil and hydrotechnical structures and quality assurance. Open Engineering, 9 (1), 420-427. https://doi.org/10.1515/eng-2019-0050

Vaughan, P. R. i Soares, H. F. (1982). Design of filters for clay cores of dams. Journal of the Geotechnical Engineering, 108, 17-31. 
Wolski, W. (1967). Odporność gruntów spoistych pochodzenia fliszowego na działanie filtracji oraz ich stosowanie do budowy rdzeni zapór sypanych i narzutowych. Warszawa: Wydawnictwo SGGW.
Yang, J., Yin, Z. Y, Laouafa, F. i Hicher, P. Y (2020). Hydromechanical modeling of granular soils considering internal erosion. Canadian Geotechnical Journal, 57 (2), 157-172. https://doi.org/10.1139/cgj-2018-0653

\section{SELECTION OF SOIL FOR TRANSITION LAYERS IN EARTH DAMS ON THE EXAMPLE OF THE ŚWINNA PORĘBA DAM}

\section{ABSTRACT}

The article presents considerations on the principles of soil selection for transition layers in earth dams, both of which also act as reverse filters. It focuses on the identification of phenomena related to filtration, in particular internal erosion of earth structures and effective methods of its prevention. The analysis of the most common principles and criteria of soil selection for the transition layers was made. The selection of soils for the transition layers of the Świnna Poręba Dam was verified.

Key words: transition layers, selection criterion, earth dam, filtration, suffusion 